\title{
Tree Species Sprouting from Root Buds in a Semideciduous Forest Affected by Fires
}

\author{
Ricardo R. Rodrigues ${ }^{1 *}$, Roseli B. Torres ${ }^{2}$, Luis A. F. Matthes ${ }^{3}$ and Alessandra S. Penha ${ }^{4}$ \\ ${ }^{1}$ Departamento de Ciências Biológicas; ESALQ/USP; rrr@esalq.usp.br; Av. Pádua Dias, 11; C. P. 9; 13418-900; \\ Piracicaba - SP - Brazil. ${ }^{2}$ Seção de Botânica Econômica; IAC. ${ }^{3}$ Seção de Floricultura e Plantas Ornamentais; \\ IAC; C. P. 28; 13001-970; Campinas - SP - Brazil. ${ }^{4}$ Pós-graduação Biologia Vegetal; Departamento de Botânica; \\ Instituto de Biologia; UNICAMP; C. P. 6109; 13081-970; Campinas - SP - Brazil
}

\begin{abstract}
Tree species which sprouted from root buds were identified in a 3.6ha area of a Semideciduous Seasonal Forest

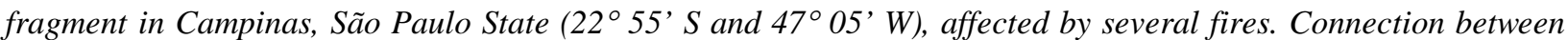
sprouts and main trunk root system was confirmed by digging and root exposure. Twenty seven tree species with root buds were identified, with a high proportion of Leguminosae species. The majority of identified species (45\%) were characteristic of initial secondary succession stages. Distances between sprouts and main trunks varied from $0.6 m$ (Guettarda viburnioides Cham. and Schltdl-Rubiaceae.) to $14.0 m$ (Colubrina glandulosa PerkinsRhamnaceae). These results lead discussions about natural and/or human-made disturbances influence on the sprouting from root buds, and its possible consequences in forest dynamics, besides the spatial occupation, and structure of populations of tree species which present their potential capacity of regeneration.
\end{abstract}

Key words: Disturbances; forests; fire; root buds; sprouting; vegetative propagation

\section{INTRODUCTION}

Human disturbances are the main factor involved in alteration of floristic composition and structural organization in the majority of Semideciduous Seasonal Forest communities in São Paulo State (Southeast Brazil) during last decades. These changes are due to deforestation, introduction of monocultures and pastures (Cavassan et al., 1984), selectively logging (Pagano et al., 1987; César and Leitão-Filho, 1990; Gandolfi et al., 1995), and specially fires (Castellani and Stubblebline, 1993; Pagano et al.,1995; Schittler et al.,1995). It is has been argued that natural regeneration and secondary succession after such disturbances in these forest fragments are related to: i) period of disturbance occurrence (Denslow, 1980); ii) initial composition and seed bank germination (Denslow, 1980; Uhl, 1982; Brokaw, 1985), and iii) sprouting of vegetative structures which remained after disturbances (Jeník, 1994; Casttellani and Stubblebline, 1993).

Vegetative regeneration of tree species includes three aspects (Jeník, 1994): the capacity of aerial branch reiteration (epicormic shoots), sprouting of basal portions of trunk (coppice shoots), and sprouting from root buds (sucker shoots). Tree sprouting from root buds follows damage to aerial portion of the main trunk (Peterson, 1975; Schier, 1975; Schier et al., 1978; Uhl, 1982; Lacey and Johnston, 1990; Jeník, 1994, Bosela et al., 1997). This is related to tropical forest habitats associated

*Author for correspondence 
with several kinds of natural and man-made disturbances, such fires (Lacey, 1974; Unwin et al., 1985; Uhl and Kauffman, 1989; Bowman, 1991; Kauffman, 1991), hurricanes (Vandermeer et al., 1990; Yih et al., 1991), floods (Gavin and Peart, 1999), and harvesting and "slash and burn" activities (Stocker, 1981; Uhl et al., 1981; Miller and Kauffman, 1997; Rijks et al., 1998; Thompson et al., 1998; Dickinson et al., 2000).

Evaluation of root sprouting in Seasonal Semideciduous Forests of Southeast Brazil, however, are still very scarce (Penha, 1998; Hayashi et al., 2001), and also others kinds of vegetative propagation, such as basal coppicing and epicormic sprouting. But tree root sprouting should be a common phenomenon in these areas, due to fragmentation and man-made disturbances. The trade-off between germination, seedling stablishment, and vegetative propagation depends on the variability of several disturbance features, in terms of type, intensity, scale, frequency, and predictability (Orbony, 1994; Stuefer, 1996). In this sense, trees that originating from root buds in tropical forest habitats could guarantee the survival of the species (Janzen, 1980; Uhl, 1982; Cook, 1985; Lacey and Johnston, 1990; Greig, 1993). The same consequences could be expected in relation to Semideciduous Seasonal forest habitats (Penha, 1998; Hayashi et al., 2001). This strategy plays an important role in the resilience of any disturbed site, that is, the degree to which community function, process composition and structure would return to their original state (Denslow, 1985). Root sprouts can show rapid growth rates because they can use the pre-existing root system and photosynthates produced by the original main trunk (Kauffman, 1991; Stocker, 1991). In relation to trees that sprout from root buds, the relationship between root suckering and several traits of disturbances, included the role of root sprouting in Semideciduous Seasonal Forests, has not been discussed yet. To explore whether these events occur in Seasonal Semideciduous Forest fragments, an urban forest remnant seriously affected by frequent fires was selected. The main questions were: i) Which tree species sprouted from root buds?; and ii) What percentage of tree species sprouted from root buds in the forest community?

\section{STUDY AREA}

The selected Semideciduous Seasonal Forest remnant belongs to Instituto Agronômico of Campinas (IAC), and is located at "Centro Experimental de Campinas", Santa Elisa Farm, in Campinas, São Paulo State, Brazil (22 ${ }^{\circ} 55^{\prime} \mathrm{S}$ and $47^{\circ} 05^{\prime} \mathrm{W}$ ). Total area is $15.87 \mathrm{ha}$ and the mean elevation of the region is $660 \mathrm{~m}$. Climate is Cwa type (Koeppen, 1948): a dry winter, with a hot and rainy summer. Mean precipitation is $1371 \mathrm{~mm} /$ year, and mean monthly temperatures varies from $23.1^{\circ} \mathrm{C}$ (January) to $17.1^{\circ} \mathrm{C}$ (July). The study area is located in the urban zone of Campinas, and it is near to a highway, which has been the source of several fires. Large fires occurred in 1983, 1985, 1988 and 1994. More than 6.0ha of the forest remnant were affected during the 1988 fire.

\section{METHODS}

Identification of tree species with root sprouts was performed five and fourteen months after September 1988 fire. Eight transects were established in 3.6ha of the area affected by fire. These transects had $100.0 \mathrm{~m}$ extension into the forest, and were located at a perpendicular position to the smallest fragment width. The distance between each of the eight transects was $10.0 \mathrm{~m}$. Individuals that sprouted from root buds and their sucker shoots were sampled along these transects. Other kinds of vegetative propagation, such as coppicing sprouts from main trunks and epicormic sprouts from tissues beneath bark on mainstems and trunks, were not included on sampling.

The connection between sprouts and main trunk root system was confirmed by digging and root exposure (Fig. 1). Alignment of young stems near a more developed trunk of the same species, and connection to roots were the evidences used to make distinction between root suckers and young stems originating from seeds. Sucker shoots also differed from saplings by absence of a primary root. The distances between root sprouts and main trunks were also measured. Tree species with root buds identified in this study were classified into successional groups (Santos et al., 1996; Bernacci and Leitão-Filho, 1997) such as: a) pioneers species; b) initial secondary species; c) late secondary species, and d) understory species. 


\section{RESULTS AND DISCUSSION}

Twenty-seven tree species with root buds (belonging to 17 families) were identified (Table 1; Fig. 1). A species survey in the same fragment, in a 0.5 ha area (Penha, 1998), identified 85 tree species $(\mathrm{DBH} \geq 5.0 \mathrm{~cm})$, belonging to 71 genera and 36 families. Therefore, the number of tree species originating from root buds represented aproximatelly $31.8 \%$ of the local tree species. Some tree species with root buds identified in this study were also recorded in secondary successional studies in another nearby Semideciduous Seasonal Forest remnant in Campinas affected by fire (Santa Genebra Reserve - $22^{\circ} 48^{\prime} \mathrm{S}$ and $47^{\circ} 07^{\prime} \mathrm{W}$ - Castellani and Stubblebline, 1993). These species were Aspidosperma polyneuron Müll. Arg., Centrolobium tomentosum Guill. ex Benth., Croton floribundus (L.) Spreng., Galipea multiflora (A. St-Hil.) Engl., Holocalix balansae Micheli, Machaerium hirtum (Vell.) Steffeld and Machaerium stipitatum Vogel.

The Leguminosae family contained the greatest number of tree species with root buds (nine species). The families Rubiaceae, Rutaceae, Sapindaceae e Solanaceae each had two species with root buds (Table 1). The Leguminosae has the greatest species richness in São Paulo State forest remnants. Sampled species with root buds at Santa Elisa forest remnant are very common in several forest fragments, showing high density values, such as Bauhinia forficata Link, Centrolobium tomentosum Guill. ex Benth., and Lonchocarpus cultratus (Vell.) A.M.G. Azevedo and H.C. Lima (Cavassan et al., 1985; Pagano et al., 1987; Rodrigues et al., 1989; Kotchekoff-Henriques and Joly, 1994; Schittler et al. 1995; Pagano et al., 1995). Therefore, the high species richness and density values within the Leguminosae in forest fragments affected by disturbances could be due, at least partially, to the high incidence of root sprouting potential in this family.

The distances observed between root sprouts and main trunks varied from $0.6 \mathrm{~m}$ (Guettarda viburnioides Cham. and Schltdt.- Rubiaceae) to $14.0 \mathrm{~m}$ (Colubrina glandulosa PerkinsRhamnaceae). This feature is the difference of root sprouting compared to other modes of vegetative propagation: root sprouts could generate aggregation of independent trunks (clones), and also allow the exploitation of places relatively distant from the main trunk. Therefore, root sprouts could be considered distinctive individuals in a phytosociological survey, if the connections between sprouts and main trunk have not been verified through exposure of root system or other methodology, such as molecular markers (Rocha et al., 1997).

Twelve of the 27 tree species with root buds (45\%) were characteristics of initials stages of secondary succession ("initial secondary species" - Table 1). The importance of initial secondary species in these Semideciduous Seasonal forest fragments has been shown (Gandolfi et al., 1995), including undisturbed forest fragments (Bernacci and LeitãoFilho, 1997; Santos et al., 1996). However, there is little information about the relationship between tree species successional traits and their potential of sprouting from root buds (Greig, 1993).

Pioneer species preferentially established through germination of their seeds, deposited on the forest soil before gap opening (Uhl et al., 1981; Young et al., 1987). However, if the intensity of fires were strong enough, the soil seed banks could not become available. In these cases, root sprouting, coppicing, and epicormic shoots could be an important strategy for regeneration in such disturbed sites. The same argument could be used to explain the presence of initial secondary species and late secondary species soon after the beginning of successional forest dynamics, if the disturbance did not eliminate totally the individuals. Therefore, sprouting from root buds could represent an effective process of spatial reoccupation, because sucker shoots have the potential to emerge at variable distances from the main trunk, and eventually develop their own adventitious root system. In this way, they would become independent, like Rollinia sylvatica (A. St.-Hil.) Mart. in this study (Fig. 1). Shoots would not be required to pass through sensitive phases of development, such as germination and seedling establishment, which depends on the intensity of disturbance (Uhl et al., 1981; Kauffman, 1991).

The manner in which root sprouts occupy space should influence the competition among individuals and species. In addition, the reproductive biology and the pollination in these tree species must also be considered, due to aggregation of clones. Finally, systematic studies of Semideciduous Seasonal forest tree species sprouting from root buds, such as sucker shoot emission, their growth and survivorship rates after 
disturbance emphasize the importance of this kind of vegetative propagation in tropical forest dynamics.

Several studies could be proposed, especially within communities that have suffered intensive intervention in their original traits, to revegetate sites with these species that recover with greater facility after a major disturbance. In this sense, it would be important to compare populations of tree species with root buds in forest fragments which suffered variable intensities of disturbance, such as occurrence of fire, to evaluate some populational quantitative traits: clone frequencies, spatial pattern, and phenological traits.

Table 1 - Tree species that sprouted from root buds in a 3.6ha area of a Semideciduous Seasonal Forest remnant, Santa Elisa Farm, Campinas, São Paulo State, Brazil. Successional classification: P: pioneers species (5/27 species); IS: initial secondary species (12/27 species); LS: late secondary species (6/27 species); US: understory species (5/27 species).

\begin{tabular}{|c|c|c|}
\hline Family & Species & Classification \\
\hline Annonaceae & Rollinia sylvatica (A. St.-Hil.) Mart. & IS \\
\hline Bignoniaceae & Tabebuia chrysotricha (Mart. ex DC.) Standl. & IS \\
\hline Boraginaceae & Cordia trichotoma (Vell.) Arrab. ex Steud. & IS \\
\hline Euphorbiaceae & Actinostemon concolor (Spreng.) Müll. Arg. & US \\
\hline Lauraceae & Cryptocarya moschata Nees & LS \\
\hline Lecythidaceae & Cariniana estrellensis (Raddi) Kunth & LS \\
\hline \multirow[t]{2}{*}{ Leguminosae - Caesalpiniodeae } & Bauhinia forficata Link & $\mathrm{P}$ \\
\hline & Hymenaea courbaril $\mathrm{L}$. & LS \\
\hline \multirow[t]{2}{*}{ Leguminosae - Mimosoideae } & Acacia polyphylla DC. & $\mathrm{P}$ \\
\hline & $\begin{array}{l}\text { Inga laurina (Sw.) Willd. } \\
\text { Centrolobium tomentosum Guill. ex Benth. }\end{array}$ & $\begin{array}{l}\text { IS } \\
\text { IS }\end{array}$ \\
\hline \multirow{4}{*}{ Leguminosae - Papilionoideae } & $\begin{array}{l}\text { Lonchocarpus cultratus (Vell.) A.M.G. Azevedo and H.C. } \\
\text { Lima }\end{array}$ & IS \\
\hline & Lonchocarpus subglaucescens Mart. ex Benth. & IS \\
\hline & Machaerium hirtum (Vell.) Stefelld & IS \\
\hline & Machaerium stipitatum Vogel & IS \\
\hline Monimiaceae & Mollinedia widgrenii A. DC. & US \\
\hline Rhamnaceae & Colubrina glandulosa Perkins & IS \\
\hline \multirow[t]{2}{*}{ Rubiaceae } & Coutarea hexandra (Jacq.) K. Schum. & US \\
\hline & Guettarda viburnioides Cham. and Schltdl. & US \\
\hline \multirow[t]{2}{*}{ Rutaceae } & Esenbeckia febrifuga (A. St.-Hil.) A. Juss. ex Mart. & US \\
\hline & Metrodorea stipularis Mart. & LS \\
\hline \multirow[t]{2}{*}{ Sapindaceae } & Allophylus edulis (A. St.-Hil.) Radlk. & $\mathrm{P}$ \\
\hline & Cupania vernalis $\mathrm{Camb}$. & IS \\
\hline Simaroubaceae & Picramnia ramiflora Planch. & LS \\
\hline \multirow{2}{*}{ Solanaceae } & Solanum granuloso-leprosum Dunal & $\mathrm{P}$ \\
\hline & Solanum pycnanthemum Mart. & $\mathrm{P}$ \\
\hline Verbenaceae & Vitex montevidensis Cham. & LS \\
\hline
\end{tabular}



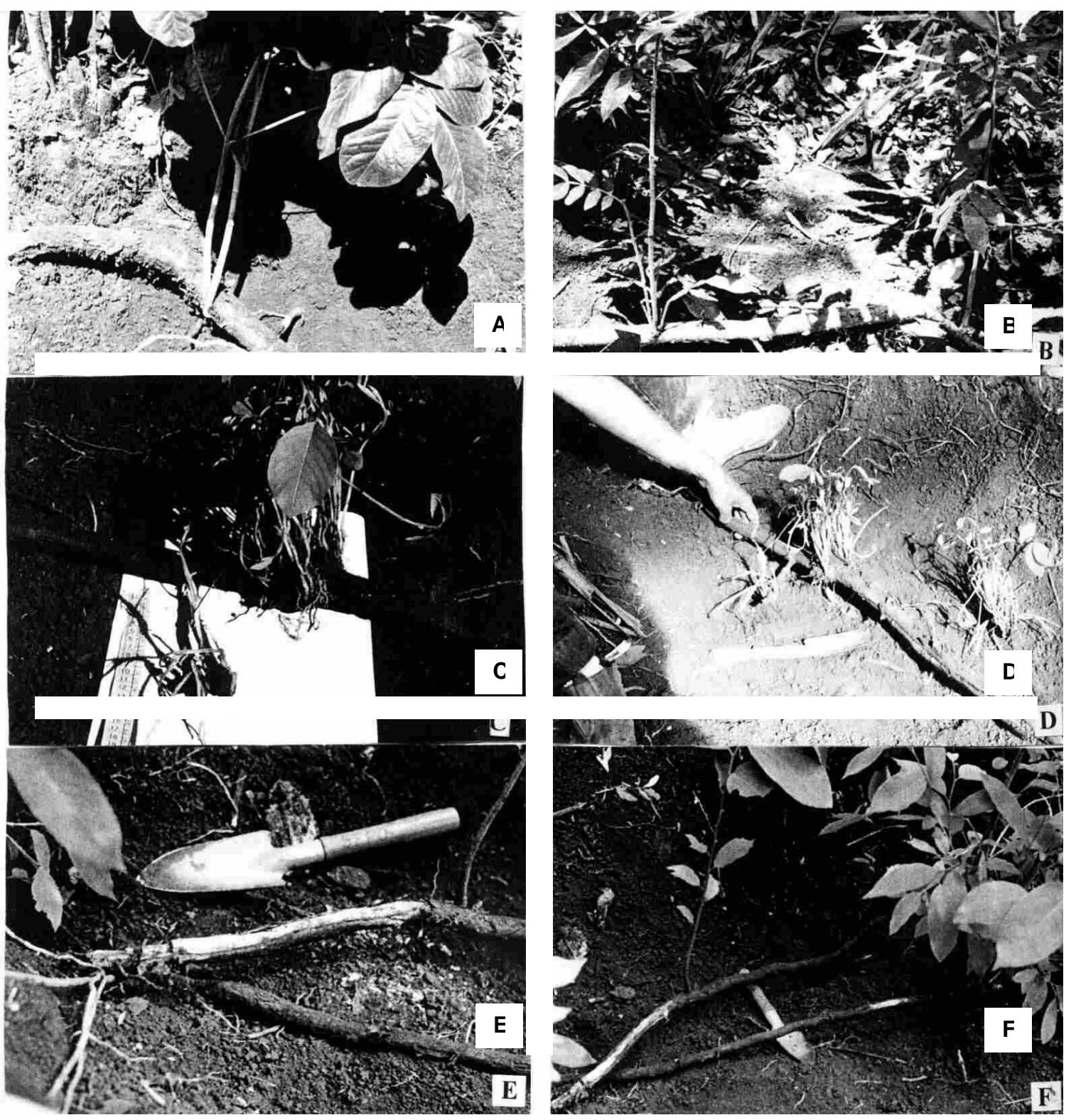

Figure 1 - A) Centrolobium tomentosum Guill. ex. Benth. root shoot - necrosis of underground tissues and the development of secondary roots; B) Inga laurina (Sw.) Willd. - root shoots emitted from root buds; C and D) Rollinia sylvatica (A. St.-Hil.) Mart. root shoots and their development 5 months after the September 1988 fire, and E and F) Rollinia sylvatica (A. St.-Hil.) Mart. root shoots after the September 1988 fire. Santa Elisa Farm, Campinas, São Paulo State, Brazil.

\section{ACKNOWLEDGMENTS}

We thank "Fundação de Amparo à Pesquisa do Estado de São Paulo" (FAPESP) for financial support, and to Instituto Agronômico de Campinas (IAC) for logistical assintance.

\section{RESUMO}

Foram identificadas as espécies arbóreas que rebrotaram a partir de raízes gemíferas em 3,6ha de um fragmento de Floresta Estacional Semidecidual em Campinas, São Paulo, alvo de frequientes incêndios. A identificação foi feita através de transectos de 100 metros de extensão no trecho de floresta selecionado e da exposição do 
sistema subterrâneo para verificar a ligação entre os brotos e seus troncos principais. Foram registradas 27 espécies que rebrotaram a partir de raízes, a maioria Leguminosae. Grande parte das espécies é característica de estádios iniciais da sucessão secundária. As distâncias máximas entre brotos e os troncos principais variaram de $0,6 \mathrm{~m}$ (Guettarda viburnioides Cham. and Schltdt.Rubiaceae) a $14 \mathrm{~m}$ (Colubrina glandulosa PerkinsRhaminaceae). Com os resultados obtidos, discutese a relação da rebrota a partir de raízes e a ação dos distúrbios, além da influência da rebrota na ocupação espacial e na estrutura de espécies arbóreas com este potencial de regeneração.

\section{REFERENCES}

Bernacci, L. C. and Leitão-Filho, H. F. (1996), Flora fanerogâmica da floresta da Fazenda São Vicente, Campinas, SP. Rev. Bras. Bot., 19, 149-164.

Bosela, M. J. and Ewers, F. W. (1997), The mode of origin of root buds and root sprouts in the clonal tree Sassafras albidum (Lauraceae). Am. J. Bot., 84, 1466-1481.

Bowman, D. M. J. S. (1991), Recovery of some Northern Australian monsoon forest tree species following fire. Proc. Royal Soc. Queens., 101, 21-25.

Brokaw, N. V. L. (1985), Treefalls, regrowth, and community structure in tropical forests. In: Pickett, S. T. A. and White, P. S. The Ecology of Natural Disturbance and Patch Dynamics. New York : Academic Press. pp. 53-69.

Castellani, T. T. and Stubblebine, W. H. (1993), Sucessão secundária inicial em mata tropical mesófila, após perturbação por fogo. Rev. Bras. Bot., 16, 181-203.

Cavassan, O.; Cesar, O. and Martins, F. R. (1984), Fitossociologia de vegetação arbórea da Reserva Estadual de Bauru, Estado de São Paulo. Rev. Bras. Bot., 7, 91-106.

César, O. and Leitão-Filho, H. F. (1990), Estudo fitossociológico de Mata Mesófila Semidecídua na Fazenda Barreiro Rico, Município de Anhembi, SP. Rev. Bras. Biol., 50, 443-452.

Cook, R. E. (1985), Growth and development in clonal plant populations. In: Jackson, J. B. C.; Buss, L. W. and Cook, R. E. (Eds.). Population biology and evolution of clonal organisms. New Haven : Yale University Press. pp. 259-296.

Denslow, J. S. (1980), Gap partitioning among tropical rainforest succession trees. Biotropica, 12, 47-55.
Denslow, J. S. (1985), Disturbance-mediated coexistence of species. In: Pickett, S. T. A. and White, P. S. (Eds.). The Ecology of Natural Disturbance and Patch Dynamics. New York : Academic Press. pp. 307-323.

Dickinson, M. B.; Whingham, D. F. and Hermann, S. M. (2000), Tree regeneration in felling and natural treefall disturbances in a semideciduous tropical forest in Mexico. For. Ecol. Manag., 134, 137-151.

Gandolfi, S.; Leitão-Filho, H. F. and Bezerra, C. L. (1995), Levantamento florístico e caráter sucessional das espécies arbustivo-arbóreas de uma Floresta Mesófila Semidecídua no Município de Guarulhos, SP. Rev. Bras. Biol., 55, 753-767.

Gavin, D. G. and Peart, D. R. (1999), Vegetative life history of a dominant rain forest canopy tree. BiotropicaI, 31, 288-294.

Greig, N. (1993), Regeneration mode in neotropical Piper: Habitat and species comparisons. Ecology, 74, 2125-2135.

Hayashi, A. H.; Penha, A. S.; Rodrigues, R. R. and Appezzato-da-Glória, B. (2001), Anatomical studies of shoot bud-forming roots of brazilian tree species. Aust. J. Bot., 49, 745-751.

Janzen, D. H. (1980), Ecologia vegetal nos trópicos. Editora Pedagógica e Universitária Ltda. São Paulo : Ed. da Universidade de São Paulo.

Jeník, J. (1994), Clonal growth in woody plants: a review. Folia Geobot. Phytotax., 29, 291-306.

Kauffman, J. B. (1991), Survival by sprouting following fire in tropical forests of the Eastern Amazon. Biotropica, 23, 219-224.

Koeppen, W. (1948), Climatologia. Fondo de Cultura Económica. México.

Kotchetkoff-Henriques, O. and Joly, C. A. (1994), Estudo florístico e fitossociológico em uma mata Mesófila Semidecídua da Serra do Itaqueri, Itirapina, SP. Rev. Bras. Biol., 54, 417-487.

Lacey, C. J. (1974), Rhizomes in tropical eucalypts and their role in recovery from fire damage. Aust. J. Bot., 22, 29-38.

Lacey, C. J. and Johnston, R. D. (1990), Woody clumps and clumpwoods. Aust. J. Bot., 38, 299-334.

Miller, P. M. and Kauffman, J. B. (1998), Effects of slash and burn agriculture on species abundance and composition of a tropical deciduous forest. For. Ecol. Manag., 103, 191-201.

Orbony, B. (1994), Spacer length in clonal plants and the efficiency of resource capture in heterogenous environments: a Monte Carlo simulation. Folia Geobot. Phytotax., 29, 139-158.

Pagano, S. N. and Leitão-Filho, H. F. (1987), Estudo fitossociológico de uma mata Mesófila Semidecídua em Rio Claro (Estado de São Paulo). Rev. Bras. Bot., 10, 49-61. 
Pagano, S. N.; Leitão-Filho, H. F. and Cavassan, O. (1995), Variação temporal da composição florística e estrutura fitossociológica de uma Floresta Mesófila Semidecídua - Rio Claro - Estado de São Paulo. Rev. Bras. Biol., 55, 241-258.

Penha, A. S. (1998), Propagação vegetativa de espécies arbóreas a partir de raízes gemíferas: representatividade na estrutura fitossociológica $e$ descrição dos padrões de rebrota de uma comunidade florestal, Campinas, São Paulo. MSc. Thesis; Universidade Estadual de Campinas, Campinas, Brazil.

Putz, F. E. and Brokaw, N. V. L. (1989), Sprouting of broken trees on Barro Colorado Island, Panama. Ecology, 70, 508-512.

Rijks, M. H.; Malta, E. J. and Zagt, R. J. (1998), Regeneration through sprout formation in Chlorocardium rodiei (Lauraceae) in Guyana. J. Trop. Ecol., 14, 463-475.

Rocha, D. M. S. and Macdowell, S. (1997), Identificação de clones de Pterodon pubescens Benth. (Leguminosae, Papilionoidade) através da técnica de RAPD. In: Leite, L. L. and Saito, C. H. (Orgs.). Contribuição ao Conhecimento Ecológico do Cerrado - Trabalhos selecionados do 3. Congresso de Ecologia do Brasil. Universidade de Brasília. Brasília, Brazil.

Rodrigues, R. R.; Morellato, L. P. C.; Joly, C. A. and Leitão-Filho, H. F. (1989), Estudo florístico e fitossociológico em um gradiente altitudinal de mata Estacional Mesófila Semidecídua, na Serra do Japi, Jundiaí, SP. Rev. Bras. Bot., 12, 71-84.

Santos, F. A. M.; Rodrigues, R. R.; Tamashiro, J. Y. and Shepherd, G. J. (1996), The dynamics of tree populations in a semideciduous forest at Santa Genebra reserve, Campinas, SE Brazil. Supplem. Bull. Ecol. Soc. Am., 77, 341-389.

Schier, G. A. (1975), Promotion of sucker development on Populus tremuloides root cuttings by an antiauxin. Can. J. For. Res., 5, 338-340.

Schier, G. A. and Campbell, Z. (1978), Aspen sucker regeneration following burning and clearcutting on two sites in the Rocky Mountains. For. Science, 24, 303-308.

Schlittler, F. H. M.; Marinis, G. and César, O. (1995), Estudos Fitossociológicos na floresta do Morro do Diabo (Pontal do Paranapanema, SP). Arq. Biol. Tec., 38, 217-234.

Stocker, G. C. (1981), Regeneration of a North Queensland rain forest following felling and burning. Biotropica, 13, 86-92.
Stuefer, J. F. (1996), Potential and limitations of current concepts regarding the response of clonal plants to environmental heterogeneity. Vegetatio, 127, 55-70.

Thompson, J; Proctor, J.; Scott, D. A.; Fraser, P. J.; Marrs, R. H.; Miller, R. P. and Viana, V. (1998), Rain forest on Maracá Island, Roraima, Brazil: artifical gaps and plant response to them. For. Ecol. Manag., 102, 305-321.

Uhl, C. (1982), Recovery following disturbances of different intensities in the Amazon Rain Forest of Venezuela. Interciencia, 7, 19-24.

Uhl, C.; Clark, K.; Clark, H. and Murphy, P. (1981), Early plant succession after cutting and burning in the upper Rio Negro region of the Amazon Basin. $J$. Ecol., 69, 631-649.

Uhl, C. and Kauffman, J. B. (1989). Deforestation, fire susceptibility, and potential tree responses to fire in the Eastern Amazon. Ecology, 71, 437-449.

Unwin, G. L.; Stocker, G. C. and Sanderson, K. D. (1985), Fire and forest ecotone in the Herberton highland north Queensland. Proc. Ecol. Soc. Aust., 13, 215-224.

Vandermeer, J.; Zamora, N.; Yih, K. and Boucher, D. (1990), Regeneración inicial en una selva tropical en la costa caribeña de Nicaragua después del huracán Juana. Rev. Biol. Trop., 38, 347-359.

Yih, K.; Boucher, D. H.; Vandermeer, J. H. and Zamora, N. (1991), Recovery of the rain forest of Southeastern Nicaragua after destruction by hurricane Joan. Biotropica, 23, 106-113.

Young, K. R.; Ewel, J. J. and Brown, B. J. (1987), Seed dynamics during forest succession in Costa Rica. Vegetatio, 71, 157-173.
Received: May 13, 2002; Revised: October 21, 2002; Accepted: May 06, 2003. 